Pobrane z czasopisma Annales I - Philosophy and Sociology http://philosophia.annales.umcs.pl Data: 26/04/2023 14:44:38

10.1515/sectio-2015-0020

A N N A L E S

UNIVERSITATIS MARIAE C URIE-SKŁODOWSKA

L U B L I N - P O L O N I A

VOL. XL, 1

SECTIO I

2015

Uniwersytet Warszawski

KATARZYNA CHOLEWIŃSKA

\title{
Wszyscy jesteśmy Kalibanami: (post)kolonialne wizje latynoamerykańskiego podporządkowania
}

We All are Calibans: (Post)Colonial Visions of the Latin American Submission

\section{WSTĘP}

Burza, jeden z ostatnich dramatów Williama Szekspira, to dzieło, które zostało rzeczywiście docenione dopiero wiele lat po śmierci swojego autora. Oryginalnie uznana za sztukę co najwyżej przeciętną, współcześnie stanowi jeden z najbardziej rozpoznawalnych utworów Szekspira. Swoją popularność zawdzięcza przede wszystkim postkolonialnym interpretacjom opisanych w niej relacji między kolonizatorami a skolonizowanymi, ale to nie postkolonialiści jako pierwsi odkryli ją na nowo. Burzę zaczęto odczytywać ponownie już w XIX wieku. W 1878 roku Ernest Renan jako pierwszy posłużył się postacią Kalibana dla ukazania problemu niezwiązanego bezpośrednio z opowiedzianą przez Szekspira historią. W swoim dramacie Kaliban. Dalszy ciag „Burzy” uczynił z Kalibana przedstawiciela ludu, który przejmuje władzę, jest jednak całkowicie niezdolny do sprawowania rządów. Renan, najprawdopodobniej w odpowiedzi na działalność Komuny Paryskiej, przekształcił Burzę w ostrą krytykę zmian społecznych, których był świadkiem¹ .

Renan nieświadomie dał początek całej serii społeczno-politycznych reinterpretacji Burzy. Szczególne zainteresowanie wzbudziła ona w Ameryce Łacińskiej, której autorzy na przestrzeni kilkudziesięciu lat zaadoptowali symbolikę tego dramatu, odczytując go przez pryzmat własnych doświadczeń historycznych i osadzając w specyficznych realiach regionu. Najbardziej znaną „debatę" przeprowadzili José Rodó i Roberto Retamar, którzy zaprezentowali dwie wizje tego, która postać (Ariel czy Kaliban) lepiej oddaje charakter Ameryki Łacińskiej. Po-

1 A.T. Vaughan, V.M. Vaughan, Shakespeare's Caliban: A Cultural History, Cambridge 1993, s. 111. 
równanie to nie było bez znaczenia, bo pokazywało, jak odmiennie widziano miejsce tego regionu w postkolonialnej rzeczywistości.

Wraz z dorobkiem szkoły postkolonialnej, w tym Subaltern Studies Group ${ }^{2}$, zaproponowane przez Retamara odczytanie Burzy stanowi interesującą refleksję na temat piętna, jakie na Ameryce Łacińskiej odcisnął kolonializm oraz jego współczesnych konsekwencji. Szczególnie interesującą figurą dla badaczy okazał się Kaliban, w którym dostrzegli uosobienie „Innego”. Jednocześnie nowa interpretacja relacji władzy pomiędzy bohaterami Burzy mocno wpłynęła na myślenie o tym, co latynoamerykańskie, postkolonialne i ,podporządkowane”.

\section{KALIBAN-KANIBAL, CZYLI OBRAZ TUBYLCA W BURZY}

Akcja Burzy (datowanej na lata 1610-1611) oficjalnie toczy się w regionie śródziemnomorskim, chociaż opis wyspy, na którą trafiają bohaterowie, zdaje się raczej nawiązywać do realiów Nowego Świata ${ }^{3}$. Głównym bohaterem dramatu jest Prospero, książę Mediolanu, który został pozbawiony tronu w wyniku spisku swojego brata Antonia oraz króla Neapolu Alonsa. Prospero i jego ukochana córka Miranda, uciekając przed spiskowcami, wypływają w morze na łodzi zaopatrzonej jedynie w wodę, żywność oraz książki. Udaje im się w końcu dopłynąć do wyspy, na której spędzają kolejnych dwanaście lat.

Na wyspie posiadający pewne magiczne zdolności Prospero uwalnia zniewolonego przez wiedźmę Sykoraks ducha Ariela, czyniąc go tym samym swoim sługą i niewolnikiem. Przetrwania w nowych warunkach uczą się od Kalibana, syna Sykoraks, który do momentu pojawienia się na wyspie Prospera i Mirandy był jej jedynym mieszkańcem. W zamian za pomoc i pokazanie im wyspy rozbitkowie uczą Kalibana swojego języka i religii. Kaliban jednak nie okazuje za to wdzięczności, przeciwnie - próbuje zemścić się na przybyszach i siłą posiąść Mirandę, za co Prospero karze go uwięzieniem w jaskini. Akcja sztuki rozpoczyna się w chwili, w której w pobliżu wyspy pojawia się statek z Antoniem i Alonsem na pokładzie. Korzystając ze swojej magii, Prospero wywołuje burzę, przez którą ulega on katastrofie, a pasażerowie - dawni spiskowcy - trafiają na wyspę.

2 Subaltern Studies Group to zespół indyjskich historyków, którzy badali tzw. grupy podporządkowane w celu dokonania rewizji historiografii Azji Południowej. Od 1982 roku wydawali własne czasopismo zatytułowane "Subaltern Studies". Zob. M.F. Gawrycki, A. Szeptycki, Podporządkowanie - niedorozwój - wyobcowanie. Postkolonializm a stosunki międzynarodowe, Warszawa 2011, s. 68.

Pod koniec XIX wieku znawcy twórczości Szekspira zaczęli powszechnie uznawać, że akcja dramatu została osadzona najprawdopodobniej na Morzu Karaibskim. W 1898 roku Sidney Lee stwierdził, że wyspa, na którą przybywa Prosper, należy do archipelagu Bermudów. „Kaliban to fikcyjny portret [...] dzikiego tubylca Nowego Świata" - pisał. Por. S. Lee, A Life of William Shakespeare, London 1898, s. 257. 
Pobrane z czasopisma Annales I - Philosophy and Sociology http://philosophia.annales.umcs.pl Data: 26/04/2023 14:44:38

Wszyscy jesteśmy Kalibanami: (post)kolonialne wizje...

W centrum dramatu znajdują się przede wszystkim polityczne rozgrywki pomiędzy włoskimi książętami. Jednak tym, co okazało się najbardziej interesujące dla odbiorców, były nie relacje między Prosperem a jego politycznymi rywalami, ale pomiędzy Prosperem a Arielem i Kalibanem, ,rdzennymi” mieszkańcami tajemniczej wyspy.

Imię Kalibana jest oczywiście anagramem słowa „kanibal”, które było zniekształconą nazwą ludu Karibów (Caribes, tłumaczeni także jako Karaibowie) i do dziś posiada niewątpliwie negatywne konotacje. W czasach Szekspira przekonanie o antropofagicznych skłonnościach zamieszkujących nowo podbite terytoria tubylców było bardzo powszechne. Nie opierało się jednak na wiarygodnych relacjach naocznych świadków tego procederu, a raczej na zasłyszanych (i niepotwierdzonych) opowieściach, które jeszcze wyraźniej uwypuklały dzikość i nieucywilizowanie tubylców. Mit ludożercy-kanibala, który (w odróżnieniu od równie mitycznego „dobrego Indianina”) stawiał zacięty opór europejskiemu podbojowi, usprawiedliwiał kolonializm w każdej formie ${ }^{4}$. Kanibal zagrażał w końcu zarówno Europejczykom, jak i Indianom.

Jednocześnie wytworzyła się charakterystyczna dla regionu latynoamerykańskiego dychotomia między „dobrym” a „złym” tubylcem. Ten pierwszy, niewinny i na swój sposób szlachetny, zasługiwał na to, aby otoczyć go opieką i zbawić jego duszę; ten drugi, niegodziwy barbarzyńca, stanowił cierń w boku kolonizatorów i musiał być tępiony. W ten sposób podbój ludności tubylczej przez Europejczyków zyskał podwójne uzasadnienie moralne - ze względu na „dobrych Indian”, których trzeba było chronić i nawracać oraz „złych kanibali”, których trzeba było zetrzeć z powierzchni ziemis. „Z punktu widzenia kolonizatorów - twierdzi Roberto Retamar, analizując funkcje mitu ludożercy w kulturze zachodniej - Karaiba należało wytępić ze względu na jego wrodzoną dzikość"6. Filip Kubiaczyk dowodzi, że „,[k]anibalizm okazał się nie tylko narzędziem generującym inność, ale również tropem kulturowym, który obnaża europejski podmiot nowożytny".

Obraz „dobrego tubylca” w kulturze europejskiej ugruntował przede wszystkim Michel de Montaigne w eseju $O$ kanibalach z 1580 roku, w którym przedstawił niewątpliwie utopijną, rajską wizję skolonizowanej ludności ${ }^{7}$. Szekspir zapewne inspirował się twórczością Montaigne’a, która została przetłumaczona na język angielski na początku XVII wieku. Jednak jeśli nie liczyć postaci Ariela, który nie jest co prawda człowiekiem, ale pozostaje rdzennym mieszkańcem

4 A. Loomba, Kolonializm/postkolonializm, Poznań 2011, s. 75.

5 F. Kubiaczyk, Nowoczesność, kolonialność i tożsamość: perspektywa latynoamerykańska, Poznań 2013, s. 174.

6 R.F. Retamar, Kaliban, [w:] Kaliban i inne eseje, Kraków 1983, s. 13.

7 Zob. M. de Montaigne, O kanibalach, [w:] Próby, t. 1, Warszawa 1985.

8 P.D. Collington, Self-Discovery in Montaigne's "Of Solitarinesse" and "King Lear", "Comparative Drama" 2001-2002, Vol. 35, No. 3-4, s. 247. 
Pobrane z czasopisma Annales I - Philosophy and Sociology http://philosophia.annales.umcs.pl Data: 26/04/2023 14:44:38

wyspy w dosłownym tego słowa znaczeniu, Szekspir zdecydowanie odszedł od wyidealizowanych opisów Montaigne’a, wzorując Kalibana na dzikich i nieokrzesanych Karaibach, których znał z innych podań.

\section{GENEZA (RE)INTERPRETACJI BURZY}

Kiedy w 1900 roku José Rodó publikował swój inspirowany Burza esej Ariel, nie przypuszczał, że w ciągu najbliższych stu lat jego metafora zostanie wywrócona na nicę, a badaczy zafascynuje nie uosabiający racjonalizm ówczesnej epoki Ariel, lecz „dziki” i brutalny Kaliban. Niemniej u progu XX wieku Rodó musiał czuć, że jego analiza stosunków Ameryki Łacińskiej z resztą świata - a przede wszystkim ze Stanami Zjednoczonymi - nie jest daleka od prawdy. W 1898 roku bowiem Stany Zjednoczone postanowiły wspomóc kubańskie powstanie narodowowyzwoleńcze, co w rzeczywistości okazało się niczym innym jak zbrojną interwencją w wewnętrzne sprawy wyspy9 ${ }^{9}$. Już w 1902 roku Kuba stała się pierwszą północnoamerykańską „neokolonią" ${ }^{10}$, ugruntowując dominację Stanów Zjednoczonych w regionie i wzbudzając falę krytyki wśród latynoamerykańskich intelektualistów, w tym Rodó.

Rodó niewątpliwie znał twórczość Paula Groussaca, który pod koniec XIX wieku jako jeden z pierwszych porównywał ekspansywne Stany Zjednoczone do „kanibala”. W podobnym duchu w 1898 roku poeta Rubén Darío zinterpretował postaci szekspirowskiego dramatu w eseju Triumf Kalibana. W tekście tym Kaliban miał symbolizować Stany Zjednoczone i proponowaną przez nie „nową” (bezwzględną, zaborczą, opartą na dążeniu do zysku wbrew wszelkim wyższym ideałom) organizację świata. W wyobrażeniu tym obywatele Stanów Zjednoczonych posiadali wszystkie najgorsze cechy: „Ideał tych Kalibanów jest ograniczony do giełdy i do fabryki. Jedzą, jedzą, liczą, piją whisky i zarabiają miliony"11. Dla Darío wartości wyznawane przez „Jankesów” stały w opozycji do wszelkiego idealizmu. Po wybuchu wojny amerykańsko-hiszpańskiej Darío bez wahania opowiedział się po stronie Hiszpanii, a nie wspieranej przez Stany Zjednoczone Kuby: „Nie, nie mogę, nie chcę stać po stronie tych bizonów o srebrnych zębach. To są moi wrogowie, to są nienawistnicy krwi łacińskiej, to są Barbarzyńcy [...]. Nie mogę być po ich stronie. Nie mogę opowiedzieć się za triumfem Kalibana"12.

Stanowisko Darío było bezpośrednio związane z faktem, że kulturowo Latynoamerykanie (a w każdym razie latynoamerykańska inteligencja) identyfikowali

\footnotetext{
9 M.C. Eakin, Historia Ameryki Eacińskiej. Zderzenie kultur, Kraków 2009, s. 242.

10 Ibidem, s. 244.

11 R. Darío, El triunfo de Calibán, "Revista Iberoamericana” 1998, Vol. LXIV, No. 1898, s. 451.

12 Ibidem.
} 
Pobrane z czasopisma Annales I - Philosophy and Sociology http://philosophia.annales.umcs.pl Data: 26/04/2023 14:44:38

Wszyscy jesteśmy Kalibanami: (post)kolonialne wizje...

się w tamtym okresie nie z Nowym, a ze Starym Światem. Nic więc dziwnego, że Darío pozostawał lojalny wobec Hiszpanii, zwłaszcza że całą ,rasę łacińską" uważał za sentymentalną, uczuciową, ale na swój sposób również silną. W ostrych słowach zaklinał się, że ,nie ma takiej góry złota, za którą moja dusza sprostytuowałaby się na rzecz Kalibana"'13.

Poglądy te przejął i rozwinął Rodó, który swojego Ariela dedykował ,amerykańskiej młodzieży". W tekście tym tytułowy Ariel, zniewolony duch powietrza, uosabia tę lepszą, szlachetną część Ameryki Łacińskiej. Reprezentuje rozum i uczuciowość, bezinteresowność działania, duchowość kulturową, urok i powab inteligencji. Kaliban z kolei staje się synonimem niskich pobudek, nieracjonalności, bezmyślności i tępoty, ale także (traktowanej jako słabość czy wada) zmysłowości. Ariel symbolizował wzniosły idealizm, Kaliban - charakteryzujący narody anglosaskie - utylitaryzm. Dedykowanie tego utworu młodym czytelnikom miało oczywiście na celu zachęcenie młodzieży Ameryki Łacińskiej do kultywowania wartości i ideałów utożsamianych z kulturą łacińską ${ }^{14}$. „Cechuje nas nordomanía” - skarżył się. „Musimy jej przeciwstawić bariery, które zgodnie wskazują nam rozum i uczucie"15. Nadmierne wzorowanie się na Stanach Zjednoczonych grozi bowiem pozbawieniem Ameryki Południowej jej ,pierwiastka łacińskiego", który stanowi o jej wyjątkowości ${ }^{16}$. Tradycja łacińska powinna zdaniem Rodó stać się inspiracją i źródłem niezależności Ameryki Łacińskiej nie tylko w wymiarze politycznym, ale i kulturowym. To zaś będzie oznaczało „zwycięstwo Ariela”, a przez to „doskonałość i porządek życia, szlachetne natchnienie myśli, bezinteresowność moralną, dobry gust w sztuce, heroizm w działaniu, subtelność w zwyczajach"17.

W następnych latach postać Kalibana była wielokrotnie reinterpretowana. W XX wieku często utożsamiano go z „uciskanym ludem”, czego przykładem były prace Jeana Guéhenno ${ }^{18}$ czy Aníbala Ponce'a ${ }^{19}$. Interesujące było także studium Octave'a Mannoniego Psychologia kolonializmu z 1950 roku, w którym autor posłużył się pojęciem „kompleksu Kalibana” na określenie „zespołu podświadomych preferencji określających jednocześnie postać patriarchalnego kolonisty i rasistę przeświadczonego, że któryś z jego podwładnych próbował zgwałcić jego córkę"20.

13 Ibidem, s. 455.

14 S. Nuccetelli, Latin American Thought: Philosophical Problems and Arguments, Cambridge 2002, s. 195.

15 J.E. Rodó, Ariel, [w:] Ariel. Motivos de Proteo, Caracas 1976, s. 34, cyt. za: F. Kubiaczyk, op. cit., s. 192.

16 Ibidem.

17 Ibidem, s. 53, cyt. za: F. Kubiaczyk, op. cit., s. 193.

18 Zob. J. Guéhenno, Caliban parle, Paryż 1928.

19 Zob. A. Ponce, Humanismo burgués y humanism proletario, Hawana 1962.

20 O. Mannoni, Prospero and Caliban: The Psychology of Colonization, London 1990, s. 110 . 
Pobrane z czasopisma Annales I - Philosophy and Sociology http://philosophia.annales.umcs.pl Data: 26/04/2023 14:44:38

Mannoni twierdził, że symbolizujący mieszkańca kolonii Kaliban podświadomie pragnie, wyczuwa i podporządkowuje się kolonizatorowi - Prosperowi ${ }^{21}$. Teoria Mannoniego, na którą wpłynął popularny wówczas nurt psychoanalizy, została odrzucona między innymi przez Frantza Fanona w książce Czarna skóra, białe maski z 1952 roku $^{22}$.

W latach 60. John Wain w Żywym świecie Szekspira wprost porównał Kalibana do skolonizowanego mieszkańca „Trzeciego Świata”. Zwracał uwagę na fakt, że Kaliban jest bohaterem, któremu należy raczej współczuć, jako że jego przeżycia do złudzenia przypominają doświadczenia narodów podbitych przez Europejczyków. „Wychowywany” przez Prospera i zmuszany do uległości Kaliban byłby szczęśliwszy, gdyby pozwolono mu trwać w jego stanie dzikości, w którym „sam był sobie królem”. W odpowiedzi na te wyrzuty Prosper przypomina Kalibanowi, że nauczył go wielu pożytecznych rzeczy, w tym mowy. Nie chodzi tu jednak o jakąkolwiek mowę, bo skądinąd wiemy, że Kaliban, chociaż „nieświadomy własnej nazwy”, potrafił „,bełkotać jak dzikie zwierzę”. Chodzi tu o mowę świata „cywilizowanego”, o słowa i pojęcia zrozumiałe dla „człowieka Zachodu". Wain podkreśla, że w tym akcie zdrady Kalibana, jakim była próba zgwałcenia Mirandy, objawił się również charakterystyczny dla tamtych czasów paniczny lęk przed mieszaniem się ras ${ }^{23}$.

Zaledwie kilka lat później Aimé Césaire wystawia swoją własną wersję $B u$ $r z y$, którą określa mianem ,adaptacji dla teatru murzyńskiego”. W sztuce Césaire’a, której akcja została umiejscowiona na Karaibach, Kaliban i Ariel są niewolnikami Prospera, z tym że Kaliban jest czarnoskóry, a Ariel jest Mulatem. Każdy z nich reprezentuje także inną odpowiedź na kolonialne działania. Kaliban chce walczyć, wzniecając powstanie przeciwko swojemu panu, podczas gdy lokalny intelektualista Ariel próbuje odwoływać się do poczucia moralności Prospera i zyskać wolność na drodze pokojowej. Kaliban ponosi klęskę. W obliczu przegranej wyrzuca Prosperowi, że go okłamywał i że zawsze uważał go za gorszego od siebie: „Prosperze, jesteś wielkim czarodziejem / Twoim znakiem szczególnym jest kłamstwo. / A okłamałeś mnie tak bardzo / O świecie, o mnie / Że ostatecznie narzuciłeś mi mój własny obraz. / Nierozwiniętego, jak sam mówiłem, niekompetentnego. / Zmusiłeś mnie, żebym tak właśnie widział siebie samego. / Nienawidzę tego obrazu! Co więcej, jest on kłamstwem!"24. W ten sposób Césaire jeszcze dosłowniej przełożył Burzę na język świata kolonialnego, interpretując relacje pomiędzy bohaterami jako między kolonizatorem i skolonizowanymi.

${ }^{21}$ Ibidem.

22 F. Fanon, Black Skins, White Masks, London 2008, s. 80-81.

23 J. Wain, The Living World of Shakespeare: a Playgoer's Guide, London 1964. Por. R.F. Retamar, Kaliban, s. 23.

24 A. Césaire, A Tempest. Based on Shakespeare's "The Tempest" Adaptation of a Black Theatre, New York 1993, s. 64. 
Pobrane z czasopisma Annales I - Philosophy and Sociology http://philosophia.annales.umcs.pl Data: 26/04/2023 14:44:38

Wszyscy jesteśmy Kalibanami: (post)kolonialne wizje...

\section{AMERYKA ŁACIŃSKA JAKO WSPÓŁCZESNY KALIBAN}

Kiedy w 1971 roku Roberto Fernández Retamar podjął z Rodó polemikę w eseju Kaliban, koncepcja Kalibana-skolonizowanego była już stosunkowo dobrze ugruntowana. Retamar jednak wyznaczył sobie interesujące zadanie, powracając niejako do źródeł reinterpretacji Burzy i przekładając jej symbolikę nie tyle na cały „Trzeci Świat”, co na Amerykę Łacińską. Retamar otwiera Kalibana pytaniem, które mu kiedyś zadano: „Czy istnieje w ogóle kultura latynoamerykańska?", a które dla niego stanowi, ni mniej, ni więcej, pytanie o fakt istnienia Ameryki Łacińskiej jako takiej. Oczywiście, jak przyznaje sam autor, jest to pytanie, które w okresie upadku tradycyjnego systemu kolonialnego można by zadać każdemu wyzwalającemu się narodowi. Skłoniło go jednak do szerszej refleksji na temat istoty „latynoamerykańskości”, szczególnie w obliczu zbliżającej się setnej rocznicy urodzin Rodó25.

Retamar decyduje się podjąć z Rodó dyskusję na temat zasadności wyboru Ariela na symbol Ameryki Łacińskiej. On sam bowiem uważa, że symbolem tym należy uczynić nie uosabiającego dobro i nowoczesność Ariela, ale Kalibana, niewolnika, który w finałowej scenie zwraca się przeciwko swojemu panu.

Naszym symbolem jest zatem nie Ariel, jak sądził Rodó, a Kaliban. Szczególnie wyraźnie dostrzegamy to my, Metysi, zamieszkujący te same wyspy, na których żył bohater Szekspira: Prosper najechał je, wybił naszych przodków, Kalibana pojmał w niewolę i nauczył go swego języka, by móc się z nim porozumieć: cóż innego może uczynić Kaliban, niż użyć właśnie tego języka - innego dziś nie posiada - aby przeklinać, życzyć, by spadła na niego „czerwona plaga”?26

Retamar nawiązywał do słynnej kwestii Kalibana: „Mowę mi dałeś; cała z tego korzyść, / Że kląć dziś mogę; niech za to na ciebie / Zaraza padnie, że mi dałeś mowę!"27. W oczach Retamara sytuacja Latynoamerykanów, których rdzenne ziemie zostały im ,wydarte” przez europejskich najeźdźców, jest porównywalna do sytuacji Kalibana. Hiszpanie i Portugalczycy, ucząc tubylców swojego języka, który stał się dominującym, zachowali się dokładnie tak, jak Prospero. Teraz, kiedy Latynoamerykanie chcą przeklinać potomków kolonizatorów, robią to zwykle w ich, a nie w swoim języku.

Retamar całkowicie przeniósł punkt ciężkości z relacji Ariel - Kaliban, która dominowała w tekście Rodó, na relację Prospero - Kaliban, która jego zdaniem była kluczowa dla zrozumienia także współczesnej Ameryki Łacińskiej.

25 R.F. Retamar, Kaliban, s. 5.

26 Ibidem, s. 24.

27 W. Shakespeare, Burza, [w:] Dzieła dramatyczne Williama Shakespeare'a (Szekspira): w dwunastu tomach, t. 11, Kraków 1985, s. 24. 
Pobrane z czasopisma Annales I - Philosophy and Sociology http://philosophia.annales.umcs.pl Data: 26/04/2023 14:44:38

Przyjęcie statusu Kalibana wymaga przemyślenia na nowo naszej historii od drugiej strony, z punktu widzenia drugiego bohatera sztuki. Jest nim oczywiście nie Ariel, lecz Prosper. Nie ma prawdziwej opozycji Ariel - Kaliban; obaj są sługami Prospera, cudzoziemskiego czarownika. Różnica polega na tym, że Kaliban jest nieokrzesanym i nieujarzmionym panem wyspy, podczas gdy Ariel, powietrzna istota, jest wyspiarskim intelektualistą ${ }^{28}$.

W 1993 roku Retamar uzupełnił Kalibana o posłowie, w którym dodatkowo wyjaśniał, że jego zdaniem Kaliban to Metys, który - chociaż od wielu lat cieszy się teoretycznie wolnością - tak naprawdę wciąż jest kolonizowany. W ten sposób nawiązał do wewnętrznych stosunków społecznych w państwach latynoamerykańskich, w których kreolska klasa rządząca traktuje Metysów i tubylców jako gorszych, niemal ,podludzi”29.

Uosobiona przez Kalibana Ameryka Łacińska zaczyna jednak być świadoma swojego pochodzenia, coraz częściej identyfikując się z podbitymi tubylcami, a nie z kolonizatorami. Kaliban pamięta, że jako syn Sykoraks jest prawowitym dziedzicem wyspy i gdyby nie kłamstwa i manipulacje Prospera, to on by nią rządził. Jest więc Ameryką Łacińską, która pamięta i która jest gotowa walczyć o to, co jej należne - Kaliban w końcu, w przeciwieństwie do Ariela, buntuje się przeciwko władzy Prospera, ściera się z nim, wyzywa go, próbuje odpłacić mu za swoją krzywdę krzywdą jego córki.

\section{ZNACZENIE SYMBOLIKI KALIBANA DLA MYŚLI POSTKOLONIALNEJ}

Wkrótce Burza stała się jednym ze sztandarowych tekstów kultury, dekonstruowanych przez badaczy szkoły postkolonialnej. Nawiązał do niej m.in. Edward Said, którego Orientalizm uznaje się za jedno z najważniejszych dzieł dla całego nurtu. Posługując się postkolonialną nomenklaturą, wskazuje on, że Kaliban, tak jak współcześni mieszkańcy Ameryki Łacińskiej, ma tożsamość hybrydyczną. Ustanowienie go symbolem tego regionu ma stanowić wstęp do debaty na temat przyszłości „kultury pragnącej osiągnąć niezależność od imperializmu”30.

Said uważał, że Burza opisuje trzy możliwe drogi dla każdej podbitej i walczącej o swoją niezależność kultury. Może ona wybrać drogę Ariela i być posłusznym sługą kolonizatora, a po odzyskaniu wolności wrócić do swojego dawnego życia (zupełnie jak Ariel, który wraca do bycia duchem powietrza), tak jakby kolaboracja z okupantem nigdy nie miała miejsca. Może również być Kalibanem, który akceptuje swoje poddaństwo, ale nie rezygnuje całkowicie $\mathrm{z}$ wyzwolenia w bliżej nieokreślonej przyszłości. W końcu zaś może być Kalibanem zbuntowanym, który

28 R.F. Retamar, Kaliban, s. 29-30.

29 Idem, Todo Calibán, Hawana 2000, s. 80-94.

30 E.W. Said, Kultura i imperializm, Kraków 2009, s. 240. 
Pobrane z czasopisma Annales I - Philosophy and Sociology http://philosophia.annales.umcs.pl Data: 26/04/2023 14:44:38

Wszyscy jesteśmy Kalibanami: (post)kolonialne wizje...

sięga do swoich przedkolonialnych korzeni, aby na nowo odkryć swoją prawdziwą tożsamość i wyzwolić się nie tylko faktycznie, ale też psychicznie ${ }^{31}$. Zdaniem Saida Kaliban rozumie, że dzieli doświadczenie bycia skolonizowanym ze wszystkimi innymi podbitymi ludami na świecie i dlatego stać go na opór ${ }^{32}$. Z kolei Rodó, który nie rozumiał prawdziwej istoty latynoamerykańskości, nie mógł zaproponować żadnego skutecznego rozwiązania dla nękających jego rodzimy kontynent problemów.

Z postkolonialnego punktu widzenia niezwykle interesujący jest w Burzy motyw języka. Ucząc Kalibana swojej mowy, Prospero chce go „ucywilizować”, ale nie dla jego własnego dobra, tylko po to, by łatwiej mu było go zniewolić. Prosperowi nic po słudze, z którym nie może się porozumieć, dlatego uczy Kalibana komunikowania się ze sobą, a dokładniej - rozumienia jego rozkazów. Przejawia się w tym tak ważna dla studiów postkolonialnych relacja władzy/wiedzy33. Język, który Prospero narzuca Kalibanowi, staje się narzędziem wyzysku, podczas gdy zawarta w księgach Prospera wiedza jest źródłem jego zdolności magicznych, z czego Kaliban doskonale zdaje sobie sprawę. W sztuce więc dosłownie wiedza świata zachodniego, który reprezentuje Prosper, daje mu nadprzyrodzone zdolności i pozwala rządzić wyspą.

Nie bez znaczenia jest kwestia seksualności Kalibana, zaś atak na Mirandę wpisuje się w stereotypy dekonstruowane przez badaczy postkolonialnych. Możliwość zgwałcenia Mirandy przez Kalibana - ,dzikiego człowieka z Nowego Świata" - stanowi jeden z największych lęków Prospera. Kaliban przejawia tutaj wszystkie cechy, które kolonizatorzy przypisywali „czarnym mężczyznom” poddającym się pożądaniu, którego obiektem staje się biała kobieta ${ }^{34}$. Kaliban nie wypiera się czynu, który prawie popełnił. Więcej, wyraża żal, że „nie uda mu się zaludnić wyspy Kalibanami"'35. W Czarnej skórze, białych maskach Fanon pisze o podobnym zjawisku, którego źródłem jest - jego zdaniem - brak akceptacji dla czarnego kochanka ze strony białego ojca. Związek z białą kobietą zaś mógł, według Fanona, być przez czarnego mężczyznę postrzegany jako sposób na awans społeczny ${ }^{36}$.

Względem nie tylko Prospera, ale także wszystkich innych bohaterów Kaliban pozostaje podporządkowany (subaltern) w rozumieniu, jakie słowu temu

31 Ibidem.

32 F. Kubiaczyk, op. cit., s. 197.

33 Pojęcie „władza/wiedza” wywodzi się z filozofii Michela Foucault, który dowodził, że mechanizmy przymusu i mechanizmy poznania są ze sobą ściśle powiązane, w związku z czym relacje między władzą a wiedzą charakteryzuje swoista zwrotność. „Ani władza nie może być praktykowana bez wiedzy, ani wiedza nie może nie płodzić władzy" - pisał. Zob. M. Foucault, Gry władzy, „Literatura na Świecie” 1988, nr 6.

34 A. Loomba, op. cit., s. 94.

35 W. Shakespeare, op. cit., s. 24.

36 F. Fanon, op. cit., s. 80. 
nadała Gayatri Chakravorty Spivak ${ }^{37}$. Nowe ujęcie podporządkowania nadal odnosiło się do relacji pomiędzy grupą dominującą a grupą zdominowaną, kładło jednak duży nacisk na kwestie reprezentacji podporządkowanych w postkolonialnej rzeczywistości. Kaliban i jemu podobni reprezentacji tej oczywiście nie mają. W oryginalnym dramacie Kaliban nie jest w końcu narratorem opowieści, a jedynie jej przedmiotem. Nic dziwnego, że Spivak także posłużyła się jego postacią jako metaforą, mówiąc: „[...] nie możemy dalej odgrywać roli Kalibana”"38.

Prospero, Miranda, Antonio, Alonso i wszystkie inne osoby, które w rzeczywistości są na wyspie obce, tworzą również system, który Spivak nazywa „kulturą imperializmu"; narzucając Kalibanowi swój język, kulturę i religię, pozbawiają go możliwości samodzielnego, nieuzależnionego od ich kultury wyrażania swoich myśli. Jak pisze Ania Loomba, „Kaliban może przeklinać, ponieważ otrzymał język tych, którzy go zniewolili. Jednak problem w tego rodzaju rozumowaniu jest taki, że działalność wywrotowa czy rebelia są w nim postrzegane wyłącznie jako produkty złego funkcjonowania samego projektu kolonialnego" 39 .

Postkolonialna „Inność” Kalibana przejawia się w jego obcości i dziwności, które uderzają w pozostałych bohaterów. W Szekspirowskim oryginale Kaliban zostaje opisany jako „dziki i potworny niewolnik” już w „Osobach dramatu”" Kaliban jest „synem ciemności” i pozostaje moralnie zepsuty, napadając na Mirandę i lżąc Prospera, chociaż ten - ze swojego punktu widzenia-zrobił dla niego dużo dobrego. Prospero stwierdza wprost, że w przypadku Kalibana: „W szpetnym ciele, szpetna dusza"41.

\section{PODSUMOWANIE}

Dla Retamara wszyscy Latynoamerykanie byli w głębi duszy „Kalibanami”. Badacze ze szkoły postkolonialnej preferowali szersze spojrzenie na symboliczne znaczenie tej postaci. Analizując podejście Szekspira do kwestii języka, wiedzy, seksualności i władzy, widzimy wyraźnie, że w swojej sztuce zawarł wszystkie te kwestie, na które szkoła postkolonialna zwraca najwięcej uwagi.

37 W ujęciu postkolonialnym podporządkowanie to cecha osób, które pod względem społecznym, politycznym i geograficznym znajdują się poza strukturą władzy hegemonicznej. Spivak precyzuje, że podporządkowanie to coś więcej niż eleganckie określenie opresji „Innego”. Zob. G.C. Spivak, Czy podporzadkowani moga przemówić?, „Krytyka Polityczna” 2011, nr 24-25. W kategoriach postkolonialnych wszyscy, którzy mają ograniczony dostęp lub w ogóle nie mają dostępu do imperializmu kulturowego. L. de Kock, Interview With Gayatri Chakravorty Spivak: New Nation Writers Conference in South Africa, "A Review of International English Literature" 1992, Vol. 23, No. 3, s. 45.

38 G.C. Spivak, A Critique of Postcolonial Reason, Harvard 1999, s. 37.

39 A. Loomba, op. cit., s. 105.

40 W. Shakespeare, op. cit., s. 9.

41 Ibidem, s. 74. 
Badacze latynoamerykańscy mieli niewątpliwie znaczący wkład w to, jakimi torami podążyły postkolonialne interpretacje Burzy. Zafascynowani jej bohaterami i ich wzajemnymi relacjami, nieustannie próbowali odnosić fikcyjny świat Burzy do tego rzeczywistego. José Rodó i Roberto Retamar położyli na tym polu największego zasługi - pierwszy nie wiedząc, do czego doprowadzi jego twórczość, drugi zaś świadomie, w duchu rodzącej się myśli postkolonialnej.

\section{BIBLIOGRAFIA}

Césaire A., A Tempest. Based on Shakespeare's "The Tempest" Adaptation of a Black Theatre, New York 1993.

Collington P.D., Self-Discovery in Montaigne's "Of Solitarinesse" and "King Lear", "Comparative Drama” 2001-2002, Vol. 35, No. 3-4.

Darío R., El triunfo de Calibán, "Revista Iberoamericana” 1998, Vol. LXIV, No. 1898.

Eakin M.C., Historia Ameryki Łacińskiej. Zderzenie kultur, Kraków 2009.

Fanon F., Black Skins, White Masks, London 2008.

Foucault M., Gry władzy, „Literatura na Świecie” 1988, nr 6.

Gawrycki M.F., Szeptycki A., Podporządkowanie-niedorozwój-wyobcowanie. Postkolonializm a stosunki międzynarodowe, Warszawa 2011.

Guéhenno J., Caliban parle, Paryż 1928.

Kock L. de, Interview With Gayatri Chakravorty Spivak: New Nation Writers Conference in South Africa, "A Review of International English Literature" 1992, Vol. 23, No. 3.

Kubiaczyk F., Nowoczesność, kolonialność i tożsamość: perspektywa latynoamerykańska, Poznań 2013.

Lee S., A Life of William Shakespeare, London 1898.

Loomba A., Kolonializm/postkolonializm, Poznań 2011.

Mannoni O., Prospero and Caliban: The Psychology of Colonization, London 1990.

Montaigne M. de, O kanibalach, [w:] Próby, t. 1, Warszawa 1985.

Nuccetelli S., Latin American Thought: Philosophical Problems and Arguments, Cambridge 2002.

Ponce A., Humanismo burgués y humanism proletario, Hawana 1962.

Retamar R.F., Kaliban, [w:] Kaliban i inne eseje, Kraków 1983.

Retamar R.F., Todo Calibán, Hawana 2000.

Rodó J.E., Ariel, [w:] Ariel. Motivos de Proteo, Caracas 1976.

Said E.W., Kultura i imperializm, Kraków 2009.

Shakespeare W., Burza, [w:] Dzieła dramatyczne Williama Shakespeare'a (Szekspira): w dwunastu tomach, t. 11, Kraków 1985.

Spivak G.C., A Critique of Postcolonial Reason, Harvard 1999.

Spivak G.C., Czy podporzadkowani moga przemówić?, „Krytyka Polityczna” 2011, nr 24-25.

Vaughan A.T., Vaughan V.M., Shakespeare's Caliban: A Cultural History, Cambridge 1993.

Wain J., The Living World of Shakespeare: a Playgoer's Guide, London 1964.

\section{SUMMARY}

In 1900 José Rodó's Ariel, an essay inspired by William Shakespeare' The Tempest, was published and gained a lot of recognition among Latin American intellectuals. In 1971 Roberto Fernández Retamar disagreed with Rodó in his essay titled Caliban. In Retamar's opinion Latin 
Pobrane z czasopisma Annales I - Philosophy and Sociology http://philosophia.annales.umcs.pl Data: 26/04/2023 14:44:38

America's symbol is not associated with spirituality and culture Ariel but Caliban, a slave who in the end turns against his master. In this context Caliban became a very interesting figure for postcolonial writers, who related him with their concept of the Other. This new way of thinking about the relationship between Tempest's characters had a great impact on the idea of what it means to be Latin American, postcolonial and subaltern.

Keywords: Ariel; Caliban; Latin American social and philosophical thought; José Rodó; Roberto Retamar; subalternity; postcolonialism; William Shakespeare's The Tempest 